\title{
On Chinglish in English Study of Vocational College Students in Leshan City, Sichuan, China
}

\author{
Ye Zhou \\ School of Foreign Language, Leshan Normal University, China
}

\begin{abstract}
In this fast-changing and globalized world, English study is more and more important for Chinese college students. Nevertheless, the differences between English and Chinese and the influence of mother tongue have caused great trouble in English study of Chinese college students, especially vocational college students. Among the problems, Chinglish is the most serious one which hinders them in making progress in English study. The author has carried out a study in Leshan Vocational and Technical College about vocational college students' Chinglish problem. Hopefully, the paper is to help vocational college students to avoid Chinglish and further to provide some advice for English teaching and learning in colleges and universities, on the basis of the findings of the study like the types and causes of Chinglish.
\end{abstract}

Index Terms - Chinglish, English study, Vocational College students

\section{INTRODUCTION}

With the development of the world, English is of vital importance to Chinese people's life and study. Chinese students spend more and more time studying English than ever. Due to the lingual and cultural differences between English and Chinese, Chinglish, as a characteristic of Chinese English study, has caused a lot of discussion and research. It is true that some Chinglish like "Long time no see" and "No Zuo, No Die" have been totally accepted by western world, but this does not mean Chinglish is not a barrier to affect communication between Chinese and foreigners. As a matter of fact, Chinglish is a big problem that hinders the cross-cultural communication and incorrect translation in signs causes inconvenience to foreigners who come to China. For example, “小心滑落” (Xiao Xin Hua Luo) with Chinglish translation "Slip Carefully" is a sign that foreigners might see in China and fail to understand. And the right English should be "Watch Your Step!" Thus, Chinglish should be avoided.

Then, what is Chinglish in the first place? Although there is no authorized definition, Chinglish refers to a combination of English and Chinese, and it is also called "Chinese English" that is produced by Chinese in their study of English due to the influence of Chinese. In the book The Translator's Guide to Chinglish, Pinkham (2007) defines Chinglish as "a kind of misshapen, hybrid language which is neither Chinese nor English but which could be regarded as English with Chinese characteristics". Besides, the Wikipedia defines Chinglish as the spoken or written English language which is influenced by Chinese.

For this problem, the author carried out a study in Leshan Vocational and Technical College about vocational college students' Chinglish problem, analyzing the various causes of Chinglish according to the results of the questionnaires and putting forward some advice for vocational college students to avoid Chinglish and for EFL teachers to improve their English teaching.

\section{Previous Studies of Chinglish}

Pinkham (2007) studied Chinglish from the perspective of translators in the book The Translator's Guide to Chinglish. And in her book, she presented the definition of Chinglish and further analyzed the causes of Chinglish such as unnecessary nouns, unnecessary verbs, unnecessary modifiers, as well as improper sentence structures, etc. A lot of examples were presented as proof. For example, "to accelerate the pace of economic reform" contains unnecessary nouns, which should be corrected to be "to accelerate economic reform". But the book failed to touch the reason why Chinglish happened and the methods to avoid Chinglish.

Then, many educators and scholars studied this topic of Chinglish and put forward different opinions from many perspectives. In the paper Lost in Translation, Huimei Liu, Frank Feather, and Wei Qian (2004) studies the main four causes of Chinglish as follows: wordiness, wrong word order, direct translation and cultural difference.

Many educators and scholars in China also analyzed Chinglish and put forward different views about the reasons for Chinglish from different perspectives. In the paper On Intrinsic and Extrinsic Causes of Chinglish, Niu Maoying (2008) probed into the external causes and internal causes by examples and analysis. The writer attributed the intrinsic reasons to learners' age and psychological structure, etc. and attributed the extrinsic reasons to mother tongue's effect on English study. Lin Qiong (2001) and Wu Hui (2010) shared the causes of Chinglish in common by analyzing the characteristics of it. Besides, they put forward some advice on how to avoid Chinglish for English learners. 


\section{RESEARCH DESIGN}

\section{Research Subjects}

Leshan Vocational and Technical College is near the writer's working unit, Leshan Normal University, so it is very convenient for the writer to do the research. The writer is acquainted with several EFL teachers in Leshan Vocational and Technical College, so the writer can invite them to hand out the questionnaires to the students they teach. Specifically, the writer chose 100 students of non-English majors in Leshan Vocational and Technical College as the study objects, who have studied English from middle school to college thus to have a certain foundation of English and are likely to use spoken and written Chinglish due to the English level. In addition, the 100 subjects consist of 50 male students and 50 female students, their age ranging from 18 to 20, their English level being diverse, and their majors including Medicine, Computer, Accounting, Hotel Management and Finance.

\section{Research Questions}

The following are the research questions about Chinglish used by students in Leshan Vocational and Technical College:

1. What do you know about Chinglish?

2. What are the most difficult problems in your English study?

3. What are the common mistakes you make in your English study?

4. Does Chinese often affect your English study?

5. Do you know the cultural difference between English-speaking countries and China?

6. What are the causes of Chinglish?

\section{Questionnaire Design}

The questionnaire on Chinglish research consists of the following five parts. Part 1 is about the research subjects' background information such as name, gender, age, major, the time of Studying English, etc. Part 2 is about the research subjects' major problems and common mistakes in English study. Part 3 is about the research subjects' views and advice about their English class. Part 4 is about the causes of Chinglish in the eyes of the research subjects. And part 5 is some Chinese sentences for the students to translate, like “我们不应该食言。”“人生的沉浮。” “在你方便的时候，”“我的 地址是四川省乐山市海棠路 1210 号。” etc.

\section{Procedures}

First of all, the author invited 20 students to finish the questionnaires as a pretest in order to find the possible questions and problems that might occur in the study. Then, the author carried out the main research by cooperating with the English teachers of the subjects, distributing the questionnaires to all 100 students. And all students are asked to finish the questionnaires honestly within 15 minutes without writing down their names.

\section{Data Collection and Data Analysis}

After all the students finished the questionnaires, the author recollected them. Among the 100 questionnaires, 96 were valid, and the other 4 were invalid in that 2 of the subjects failed to complete all the questions while the other 2 did more choices than is required. Finally, the author put the data of the 96 questionnaires into the computer for statistical analysis by SPSS16.0.

\section{MAJOR Findings of THE RESEARCH RESUlts}

After the data collection and data analysis, the writer will touch the common mistakes of Chinglish and go further to analyze the causes of those mistakes, hoping to find clues and present advice for both EFL teachers and vocational college students.

\section{Common Mistakes of Chinglish}

After the further analysis of the data, the author concluded the following common mistakes in terms of Chinglish.

1. Misuse of words: For example, “我们不应该食言。” Chinglish translation is “We should not eat our words.” This is a wrong use of words. The students translate the sentence word for word. And the correct translation should be "We should not break our words."

2. Improper word order: For example, “人生的沉浮。”Chinglish translation is “the downs and ups of life." This is a wrong word order. The students translate the sentence in a Chinese order, failing to realize the different expression in English. And the correct translation should be "the ups and downs of life."

3. Improper Collocation: For example, “爸爸总爱发脾气。” Chinglish translation is “Dad always like losing his temper." This is a wrong collocation. The students have a wrong understanding of the verb "like" and use it by an improper collocation. And the correct translation should be "Dad is apt to lose his temper."

4. Improper Subject: For example, “在你方便的时候, ” Chinglish translation is “when you are convenient, ” This is a wrong subject. The students fail to master the right subject of the word "convenient". And the correct translation should be "when it is convenient for you".

5. Improper Voice: For example, “这本书是他姐姐送他的。” Chinglish translation is “The book is his sister gave him." This is a wrong voice. The students are affected by their mother tongue in a negative way, forgetting the active voice and passive voice in English. And the correct translation should be "The book was given by his sister." 
6. Improper Sentence Order: For example, “我的地址是四川省乐山市海棠路 1210 号。”Chinglish translation is "My address is Sichuan Province, Leshan City, Haitang Road No. 1210." This is a wrong order. The students follow their Chinese thinking pattern to translate the location and place word for word. And the correct translation should be "My address is No. 1210 Haitang Road, Leshan City, Sichuan Province."

7. Improper Dangling Modifier: For example, “天气很好, 同学们决定出去春游。” Chinglish translation is “Being a fine day, the students decided to have a spring outing." This is a wrong dangling modifier. The students fail to master the different subjects of the main clause and subordinate participle structure. And the correct translation should be "It being a fine day, the students decided to have a spring outing."

8. Redundancy: For example, “我的妹妹业余时间喜欢唱歌。” Chinglish translation is “My sister likes singing songs in her spare time." This is redundancy. The students fail to master the meaning and usage of the word "sing". And the correct translation should be "My sister likes singing in her spare time."

9. Comma Splice: For example, “已经五点半了, 我们天黑前到不了城镇。” Chinglish translation is “It is nearly half past five, we cannot reach town before dark. " This is a comma splice. This is a common mistake for students who are affected by their Chinese. They tend to use comma splice or run-on sentences. And the correct translation should be "It is nearly half past five. We cannot reach town before dark." or "It is nearly half past five, and we cannot reach town before dark."

10. Cultural Difference: For example, “送别外国朋友时“慢走，走好。” Chinglish translation is “Walk slowly, walk well." This is a wrong translation due to cultural difference. The students translate in this way because of the long-established way of parting to show politeness, failing to realize that this way of parting will cause uncomfortable feeling to foreigners. And the correct translation should be "Take care." or "Goodbye."

\section{Causes of Chinglish}

1. Chinese Thinking Pattern: The deep-rooted thinking pattern shaped from the very beginning of one's life decides the way how people deal with language. Though vocational college students make great efforts to learn the western thinking pattern, they achieve little and they are consciously or subconsciously affected by their Chinese thinking pattern. In the process of translation, the Chinese thinking pattern has a great impact on the students in a negative way, which inevitably causes Chinglish among vocational college students.

2. Negative Transfer by Mother Tongue: Language learners' mother tongue is a decisive factor in second language acquisition. Adults' mother tongue system has developed to a certain degree that it resists a new language. The older the language learners are, the more difficult for them to learn a second language. When vocational college students learn English, they tend to be affected by their mother tongue in a negative way. Thus, this negative transfer by mother tongue is an obvious cause for Chinglish.

3. Improper Translation Method: The data of questionnaires show clearly that most of the vocational college students may use improper translation method when they deal with English. Actually, they use the same translation method from the beginning to the end in all conditions, failing to adjust the methods flexibly. In the process of English to Chinese translation, vocational college students tend to use a word-for-word translation method which is obviously improper and will consequently cause Chinglish.

4. Cultural Difference: The data of questionnaires show clearly that most of the vocational college students know little about the culture of English-speaking countries. And what makes things worse is that they lack the interest in the culture and never take initiatives to study it. Due to the cultural difference between China and English-speaking countries, the translation made by them is apt to be Chinglish.

\section{IMPLICATIONS OF THE RESEARCH}

The above-mentioned findings trigger the following implications not only for vocational college students to avoid Chinglish but also for EFL teachers to improve their English teaching.

1. Fostering a Good Habit of Thinking in English

When we learn a second language, we should not always translate it into our mother tongue. Only when we totally forget our mother tongue in the process of using the second language can we truly master the second language. In English teaching and learning, both the teachers and students should recognize the significance of thinking in English. Only in this way can students avoid Chinglish and improve their English level. Besides, in their daily life, the students should foster the good habit of using English-English dictionaries and reading original English novels without Chinese translation. They should think of English whatever they see and whatever they hear. Finding every chance to practice English is a must for English learners. The more input, the more output.

2. Taking Advantage of Positive Transfer of Mother Tongue and Avoiding Negative Transfer of Mother Tongue

The EFL teachers should help the students to realize in a right way the positive transfer and negative transfer of mother tongue. Then, on one hand, the students can take good advantage of positive transfer of mother tongue like the similar pronunciation, the common parts of speech and sentence constituents, the common sentence types and patterns as well as the similar cultural knowledge between English and Chinese; but on the other hand, the students should try to avoid negative transfer of mother tongue, clarifying the differences between English and Chinese like the singular and plural forms as well as the tense of English verbs. Only when the students master the difference between English and 
Chinese can they avoid being affected by Chinese in a negative way.

3. Improving Translation Methods

The EFL teachers should help students to master different kinds of translation methods like literal translation and free translation as well as grammar-translation method, etc. The students should learn to adjust the translation methods flexibly according to different context. The students need to realize the improper translation method they often use, avoiding Chinglish in the first place. Besides, the EFL teachers should improve their teaching by promoting their teaching methods, so as to arouse the students' interest in English study. Only when the students master diverse translation methods can they avoid Chinglish.

4. Improving Cultural Awareness

When it comes to English study, it is widely acknowledged that both language points and cultural knowledge play equal and vital importance in communication. Therefore, in English teaching, the EFL teachers should not only teach English vocabulary and grammatical points to the students, but also impart social customs and historical background of English-speaking countries to the students. Only in this way can the students improve their English level and avoid pragmatic mistakes especially Chinglish. For example, animals like dogs have different meanings and connotations in different cultures, being treated as inferior ones in most Chinese idioms like “偷鸡摸狗”, “狗急跳墙” and “狐朋狗友” while being treated as loyal companions and positive ones in most English idioms like "He is a luck dog" and "Love me, love my dog."

\section{CONCLUSION}

It is true that Chinglish is a specific problem that occurs in the process of Chinese students' learning English, which obviously affect the English level of the students and impair the communication between the foreigners and the students. According to the above-mentioned study, Chinglish are primarily caused because of Chinese thinking pattern, negative transfer by mother tongue, improper translation method and lack of cultural knowledge of English-speaking countries. In order to improve the English level of vocational college students and to improve the EFL teaching, the writer puts forward some advice to Chinglish avoidance. The EFL teachers and the vocational college students should make joint efforts to tackle the problem. On one hand, the EFL teachers should improve their teaching methods, focusing not only on the basic skills of English, but also different translation methods. And on the other hand, the vocational college students should form a good habit of thinking in English and take initiative to learn the culture of English-speaking countries. Although there are limitations in the study due to subjective and objective factors, hopefully the paper is helpful for vocational college students to avoid Chinglish and for EFL teachers to improve their English teaching.

\section{REFERENCES}

[1] Awes, C. (1992). Classroom: Goals, Structure, and Student Motivation. Journal of Educational Psychology: 3, $34-36$.

[2] Altarriba, J. (1993). Cognition and Culture: A Cross-Cultural Approach to Psychology. New York: Elsevier Science Publisher, B.V.

[3] Bialystok, Ellen. (1982). On the Relationship between Knowing and Using Linguistic Forms. Applied Linguistics, 3 (3), 181-206.

[4] Blum-Kulka, Shoshana. (1982). Learning How to Say What You Mean in a Second Language: A Study of Speech Act Performance of Learners of Hebrew as a Second Language. Applied Linguistics, 3 (1),29-59.

[5] Cole, M. S. Scriliner. (1974). Culture and Thought: A Psychological Introduction. Manhattan: John Wiley \&Sons, Inc.

[6] Dulay H, Burt M, Krashen S. (1982). Language Two. Oxford: Oxford University Press

[7] Davies, P \& Pearse, E. (2002). Success in English Teaching. Shanghai: Shanghai Foreign Language Education Press.

[8] Dweck, C. S. Leggett, E. L. (1988). A Social-cognitive Approach to Motivation and Personality. Psychological Review: (2) 94-95.

[9] Ellis,R. (2005). Analyzing learner language. London: Oxford University Press.

[10] Ellis, Rod. (1999). Understanding Second Language Acquisition. Shanghai: Shanghai Foreign Language Education Press.

[11] Edge, J. (1989). Mistakes and correction. London: Longman Hamp-Lyons.

[12] Faerch, Claus. Gabriele, Kasper. (1984). Pragmatic Knowledge: Rules and Procedures. Applied Linguistics, 5 (3), $214-225$.

[13] Freeman. D. and J. C. Richards. (1996). Teacher Learning in Language Teaching Cambridge: Cambridge University Press.

[14] Gredler, M. (2004). Learning and Instruction: Theory into Practice. Beijing: China Light Industry Press.

[15] Gillian Brown and George Yule. (1983). Discourse Analysis. London: Cambridge University Press.

[16] Gass, Susan; Selinker, Larry. (2008). Second Language Acquisition: An Introductory Course. New York, NY: Routledge.

[17] Gudykunst, W. B. Young, Yun, Kim. (2003). Communicating with Strangers: An Approach to Inter-cultural Communication. USA: McGraw-Hill.

[18] Huimei Liu, Frank Feather, and Wei Qian. (2004). Lost in Translation. US-China Foreign Language, 2.10, pp. 18-20.

[19] He Daokuan. (1988). Nonverbal Communication. In Hu Wenzhong (Ed.) Intercultural communication: What it Means to Chinese Learners of English (pp.137-166). Shanghai: Shanghai Translation Press.

[20] Halliday M.A.K. (1964). The linguistic science and language teaching. London: Longman\& Green Co. Ltd.

[21] Halliday, M.A.K; and Ruqayia Hasan. (1976). Cohesion in English. London: Longman.

[22] Hinkel, Eli. (2001). Culture in Second Language Teaching and Learning. Shanghai: Shanghai Foreign Language Education Press.

[23] James, C. (1998). Errors in language learning and use: Exploring error analysis. London: Longman. 
[24] Karry A. Samovar et al., (2000). Communication between Cultures. Beijing: Foreign Language Teaching and Research Press.

[25] Kirkpatrick, (1997). Chinese and A. Traditional Chinese Text Structures and Their Influence on the Writing in Chinese and English of Contemporary Mainland Chinese Students. Journal of Second Language Writing, (3), 223-224.

[26] Kachru,Braj. (1985). Institutionalized Second Language Varieties. Oxford: Pergamon Press.

[27] Kasper,G. (1992). Pragmatic Transfer. In Studies in Second Language Acquisition (1): 3-8.

[28] Lucy, J.A. (1992). Language Diversity and Thought: A Reformulation of the Linguistic Relativity Hypothesis. Cambridge: Cambridge University Press.

[29] Lin Qiong. (2001). On China English and Chinglish. Journal of Gansu Education College. (3) 45-47.

[30] L.\&Condom W. (2000). Assessing the portfolio. New Jersey: Hampton Press.

[31] McCalI,R.B., E.Havemann. (1976). Psychology: An Introduction. New York: Harcourt Brace Jovanovich, Inc.

[32] Mondria,J.\&Witde Boer. (1991). The effects of contextual richness on the guess ability and the retention of words in a foreign language. Applied Linguistics, (12):232-241

[33] Niu Maoying. (2008). On Intrinsic and Extrinsic Causes of Chinglish. Xian: School of Foreign Language in Northwest University.

[34] Nemser, W. (1971). Approximative systems of foreign language learners. IRAL, 9, (2):115-124.

[35] Omaggio, A. (2001). Teaching language in context. Proficiency oriented instruction. (3rd ed.). Boston, MA: Heinle\&Hainle Publishers.

[36] Pajares, E. (2006). Self-efficacy beliefs in academic settings. Review of Educational research, 6 (4).541-563

[37] Pinkham. (2007). The translator's guide to Chinglish. Beijing: Foreign Language Teaching and Research Press: 3, 18, 50, 228, 386.

[38] Rod Ellis. (1997). Second Language Acquisition. London: Oxford University Press.

[39] Robertson, S.I. (1999). Types of Thinking. London: Routeledge.

[40] Ron Scollon. (2000). Intercultural Communication: A Discourse Approach. Beijing: Foreign Language Teaching and Research Press.

[41] Ron Scollon. Suzanne Wong Scollon. (2000). Contrastive Discourse in Chinese and English. Beijing: Foreign Language Teaching and Research Press.

[42] Richards J. (2000). Longman Dictionary of Language Teaching and Applied Linguistics. Beijing: Foreign Language Teaching and Research Press: 562.

[43] Selinker, L., \& Lamendella, J. T. (1980). Fossilization in interlanguage learning. Boston. MA: Little, Brown and Company.

[44] Sakai, H, \&Kikuchi, K. (2009). An analysis de-motivators in the classroom. System, (37), 51-54

[45] Slavin, R .E. (1988). Educational Psychology Theory into Practice. USA: United States of America Prentice Hall.

[46] Strunk,W. (1979). The Elements of Style. Shanghai: Education Press:23.

[47] Schumann, J. H. (1975). Affective factors and the problem of age in second language acquisition. Language Learning: 25, 205-235.

[48] Todd,L. \& LHancock. (1990). International English Usage. New York: New York University Press.

[49] Tsuchiya, M. (2004). Japanese university students de-motivation to study English. The chugoku Academic Society of English Language Education. (34).54-56

[50] Trask,L. (1995). A Dictionary of Grammatical Terms in Linguistics. New York: Routledge.

[51] VanPatten, Bill; Benati, Alessandro G. (2010). Key Terms in Second Language Acquisition. London: Continuum.

[52] Woods, D. (1996). Teacher Cognition in Language Teaching. Cambridge: Cambridge University Press.

[53] Wu Hui. (2010). On Causes and Countermeasures of Chinglish. School of Foreign language of Shanghai Second Polytechnic University. Teaching and Management. (1). 27-29.

[54] Wright, Horn and Sanders. (1997). Teacher and Classroom Context Effects on Student Achievement: Implications for Teacher Evaluation, Journal of Personnel Evaluation in Education. 11:57-67.

[55] Young, L. (1994). Talk and Culture in Sino American Combination. England: Cambridge University Press.

[56] Yip,V. (1995). Inter-language and Learnability: from Chinese to English. Amsterdam: John Benjamins Publishing Company.

[57] Zimmerman, B. J. (2000). Self-efficacy; An essential motive to learn. Contemporary Educational Psychology, 25. 81-88

Ye Zhou was born in Leshan City, Sichuan Province, China in 1983. She received her Master's Degree in Comparative Literature and World Literature from Sichuan International Studies University, China in 2012.

She is currently a lecturer in the School of Foreign Languages, Leshan Normal University, Sichuan, China. Her research intere sts include English teaching and American literature. 